\title{
Supplementation with difructose anhydride III promotes passive calcium absorption in the small intestine immediately after calving in dairy cows
}

\author{
M. Teramura, ${ }^{*} \dagger^{1}$ S. Wynn, ${ }^{*}$ M. Reshalaitihan, $\ddagger$ W. Kyuno, $\dagger$ T. Sato, $\dagger$ M. Ohtani, $\dagger$ C. Kawashima, $\ddagger$ \\ and M. Hanadał \\ *United Graduate School of Agricultural Sciences, Iwate University, Morioka, Iwate, 020-8550, Japan \\ †Nippon Beet Sugar Manufacturing Co. Ltd., Obihiro, Hokkaido, 080-0831, Japan \\ †Obihiro University of Agriculture and Veterinary Medicine, Obihiro, Hokkaido, 080-8555, Japan
}

\begin{abstract}
The incidence of hypocalcemia increases in highparity dairy cows because resorption of bone $\mathrm{Ca}$ is delayed in these animals, and they appear to have a reduced ability to absorb $\mathrm{Ca}$ from the intestine during the early postpartum period. Difructose anhydride (DFA) III has been shown to promote the absorption of intestinal $\mathrm{Ca}$ via a paracellular pathway. However, past studies have not reported this effect in peripartum dairy cows. Therefore, we investigated the effect of DFA III supplementation on Ca metabolism during the peripartum period to determine whether DFA III promotes intestinal Ca absorption via this route. Seventy-four multiparous Holstein cows were separated into DFA and control groups based on their parity and body weight. The feed of the DFA group was supplemented with $40 \mathrm{~g} / \mathrm{d}$ of DFA III from -14 to $6 \mathrm{~d}$ relative to calving. The control group did not receive DFA III. At calving ( $0 \mathrm{~h}$ relative to calving), serum Ca declined below $9 \mathrm{mg} / \mathrm{dL}$ in both groups. However, serum Ca concentrations were greater in the DFA group than in the control group at $6,12,24$, and $48 \mathrm{~h}$ relative to calving, and the time required for serum $\mathrm{Ca}$ to recover to $9 \mathrm{mg} / \mathrm{dL}$ during the postpartum period was shorter in the high-parity cows in the DFA group than in those in the control group. Parathyroid hormone concentrations increased immediately after calving in both groups and were greater in the control group than in the DFA group at 12 and $24 \mathrm{~h}$ relative to calving. Serum 1,25-dihydroxyvitamin $\mathrm{D}$ concentrations increased at 0 and $12 \mathrm{~h}$ relative to calving in both groups and were higher in the control group than in the DFA group at $72 \mathrm{~h}$ relative to calving. Serum concentrations of the boneresorption marker cross-linked N-telopeptide of type I collagen (NTX) were not different between the groups
\end{abstract}

Received March 15, 2015.

Accepted August 14, 2015.

${ }^{1}$ Corresponding author: teramu@nitten.co.jp during peripartum period, and serum NTX in all cows was lower at $0,6,12,24,48$, and $72 \mathrm{~h}$ relative to calving than at $-21,4$, and $5 \mathrm{~d}$ relative to calving. Thus, DFA treatment induced faster recovery of serum Ca, although bone resorption was restrained. In conclusion, DFA III promotes intestinal passive Ca absorption via the paracellular pathway during the early postpartum period; this absorption is unaffected by aging.

Key words: hypocalcemia, calcium, difructose anhydride (DFA) III, paracellular pathway, dairy cow

\section{INTRODUCTION}

Hypocalcemia is a condition in which serum Ca declines due to the disruption of Ca homeostasis by the large change in demand for $\mathrm{Ca}$ that occurs at the onset of lactation (DeGaris and Lean, 2008). Hypocalcemia is considered a gateway disease that greatly reduces the chance for full productivity in the ensuing lactational period. Hypocalcemia renders cows more susceptible to other disorders, such as mastitis, displaced abomasum, retained placenta, and ketosis (Curtis et al., 1983). Methods to prevent the occurrence of hypocalcemia have been proposed that involve limiting the Ca supply before calving (Goings et al., 1974), feeding or injecting exogenous vitamin $\mathrm{D}$ at 10 to $14 \mathrm{~d}$ before calving (Hibbs and Pounden, 1955), and adjusting the DCAD by supplying anions (Block, 1984). However, it is almost impossible to formulate an effective diet containing a very low level of $\mathrm{Ca}$ (NRC, 2001), and the effective dose of 1,25-dihydroxyvitamin $\mathrm{D}\left[\mathbf{1 , 2 5}-(\mathbf{O H})_{2} \mathrm{D}\right]$ before calving is close to the toxic dose (Goff and Horst, 1990). Furthermore, it is difficult to adjust the DCAD because anionic salts are of low palatability (Charbonneau et al., 2006), and a large effort is required to collect samples from each cow to determine the $\mathrm{pH}$ of the urine. Subclinical hypocalcemia, defined as a plasma Ca concentration of $<8 \mathrm{mg} / \mathrm{dL}$, affects approximately $50 \%$ of all multiparous cows (Reinhardt et al., 2011); hence, various methods have been proposed to prevent the occurrence of hypocalcemia. 
Three routes exist by which to recover reduced serum Ca levels: (1) resorption of $\mathrm{Ca}$ stored in bones (bone resorption), (2) dietary provision of $\mathrm{Ca}$, and (3) reabsorption by the renal tubules (NRC, 2001). However, in parturient cows, the total amount of $\mathrm{Ca}$ that can be recovered and the extent of urinary $\mathrm{Ca}$ excretion are relatively small (Goff, 2006), and Ca homeostasis has been reported to depend on intestinal $\mathrm{Ca}$ absorption immediately after calving because bone resorption is delayed for 1 wk or more following calving (Ramberg et al., 1984) unless cows are fed a low-DCAD diet (Kurosaki et al., 2007).

Transepithelial Ca transport in the intestine occurs via 2 routes: a transcellular pathway and a paracellular pathway (Bronner, 1998). The previously mentioned methods of preventing hypocalcemia by limiting Ca supply and injecting exogenous vitamin D before calving promote $\mathrm{Ca}$ absorption via the transcellular pathway by stimulating the production of $1,25-(\mathrm{OH})_{2} \mathrm{D}$. However, because the number of vitamin $\mathrm{D}$ receptors (VDR) within the intestinal epithelial cells declines with aging (Horst et al., 1990), the ability to absorb $\mathrm{Ca}$ through the transcellular pathway of the intestinal epithelial cells is reduced in older cows (Horst et al., 1997). In contrast, Ca absorption via the paracellular pathway occurs via passive transport through tight junctions, which is affected by the Ca concentration gradient (Bronner, 1987) that occurs when cows are administered oral Ca drenches (Goff and Horst, 1993). Tight junctions, which are located at the apical cell-cell interfaces of adjacent epithelial cells, form a continuous intercellular barrier that allows selective ion permeation between these cells (Tang and Goodenough, 2003). Paracellular transport via tight junctions is physiologically regulated by various intracellular signaling pathways (Karczewski and Groot, 2000). Extracellular stimuli, including food factors, drugs, and chemicals, reportedly affect paracellular transport through signal transduction (Nusrat et al., 2000). Medium-chain fatty acids have been shown to increase paracellular transport through the contraction of actin filaments following the phosphorylation of myosin light chains by $\mathrm{Ca}^{2+} /$ calmodulin-activated myosin light-chain kinase (MLCK) in Caco-2 cells (Lindmark et al., 1998). Lysophosphatidic acid increases the permeability of tight junctions by causing actin contraction via a Rhokinase-dependent pathway (Hirase et al., 2001).

Difructose anhydride (DFA) III is an indigestible oligosaccharide that is enzymatically synthesized from inulin (Kikuchi et al., 2004) and cannot be degraded by typical strains of intestinal microbes such as Bifidobacterium, Lactobacillus, and Bacteroides spp. (Saito and Tomita, 2000) because the DFA III hydrolytic enzyme is produced only by Arthrobacter sp. H65-7
(Sakurai et al., 1997). In vitro experiments conducted using the small intestines of rats (Suzuki et al., 1998; Mineo et al., 2002) and duodenum of cows (Teramura et al., 2015) have shown that Ca absorption via the paracellular pathway can be accelerated by agents that act upon tight junctions. Difructose anhydride III promotes paracellular transport by reduced transepithelial electrical resistance (TEER) and enhances the transport of paracellular markers (Suzuki and Hara, 2004, 2006) with alterations to caludin-1, a component protein of tight junctions and actin filament in Caco2 cells (Suzuki and Hara, 2006). However, the DFA III-induced reduction in TEER is not attenuated by any inhibitors of several kinases mentioned above; thus, the cellular mechanisms underlying the enhancement of paracellular transport by DFA III are distinct from other factors (Suzuki and Hara, 2006). The ruminal microorganisms of dairy cows have difficulty digesting DFA III (Sato et al., 2006). Therefore, intact DFA III reaches the duodenum $1 \mathrm{~h}$ after oral ingestion (Nakai et al., 2007), and approximately $70 \%$ of DFA III reaches the duodenum intact in dairy cows (Teramura et al., 2015). Furthermore, DFA III promotes in vitro intestinal $\mathrm{Ca}$ absorption via the paracellular pathway in cattle and, by supplementing the diet of dairy cows with DFA III during the close-up period (i.e., 3 wk before parturition), postcalving hypocalcemia can be prevented (Sato et al., 2007). In addition, other effects of DFA III have been identified, including an effect on the absorption of IgG from colostrum in newborn calves (Sato et al., 2012) and a positive effect on the overall health of calves (Matsumoto et al., 2009; Takagi et al., 2011).

Feeding DFA III to peripartum dairy cows promotes intestinal $\mathrm{Ca}$ absorption via the paracellular pathway, which is unaffected by aging, whereas the cow's ability to absorb Ca via the transcellular pathway of intestinal epithelial cells, which is dependent on the number of VDR within the intestinal epithelial cells, declines with age. However, previous studies did not indicate that feeding DFA III promotes passive intestinal Ca absorption via the paracellular pathway in peripartum dairy cows. Therefore, the objective of this study was to clarify the effect of feeding DFA III on Ca metabolism during the parturition period.

\section{MATERIALS AND METHODS}

The study was conducted between October 2012 and April 2014 at the Field Center of Animal Science and Agriculture of Obihiro University of Agriculture and Veterinary Medicine, Japan. The experimental protocols complied with the regulations of the Guide for 
the Care and Use of Agriculture Animals of Obihiro University, Japan.

\section{Animals}

Twenty-one days before the expected calving day (d 259 of gestation), 74 multiparous Holstein cows were divided into 2 groups of 37 animals (control and DFA groups) consisting of cows of similar parity and BW. The mean values for the control and DFA groups, respectively (means $\pm \mathrm{SE}$ ), were as follows: parity after calving $=3.7 \pm 0.3$ and $3.7 \pm 0.3$; BW at $21 \mathrm{~d}$ before the expected calving day $=771 \pm 12$ and $768 \pm 10 \mathrm{~kg}$; BCS (Edmonson et al., 1989) at $21 \mathrm{~d}$ before expected calving $=3.51 \pm 0.02$ and $3.54 \pm 0.02$; and 305-d milk yield during the previous lactational period $=9,465$ \pm 228 and $9,690 \pm 270 \mathrm{~kg}$. The 2 groups were housed in a testing facility containing stalls and Calan doors (Tsuchiya Dairy Equipment Mfg. Co. Ltd., Obihiro, Japan) located in the Center, and they had free access to water and salt mineral blocks (KNZ salt licks, Hengelo, the Netherlands). The cows were fed $10.9 \pm 0.1$ $\mathrm{kg}(\mathrm{DM})$ of a TMR per day when they were dry (Table 1) and were fed grass hay ad libitum from $21 \mathrm{~d}$ prepartum until calving. After calving, the cows were fed a
TMR for lactating cows that was formulated to supply the nutrients required to sustain milk production of 35 $\mathrm{kg} / \mathrm{d}$ (NRC 2001; Table 1) and grass hay ad libitum. From $14 \mathrm{~d}$ before calving until $6 \mathrm{~d}$ postpartum, the diet of the DFA group was supplemented with $200 \mathrm{~g} / \mathrm{d}$ of DFA pellets containing 20\% DFA III (Nippon Beet Sugar Manufacturing Co. Ltd., Tokyo, Japan; Table 1). The diet of the control group was supplemented with $160 \mathrm{~g} / \mathrm{d}$ of control pellets that did not contain DFA III (Table 1). Therefore, the DFA diet was supplemented with $40 \mathrm{~g} / \mathrm{d}$ of DFA III. To supplement dietary Ca, $200 \mathrm{~g}$ of dibasic calcium phosphate $\left(\mathrm{CaHPO}_{4} \cdot 2 \mathrm{H}_{2} \mathrm{O}\right.$; Obanaya Cementex Co. Ltd., Aichi, Japan; containing $46 \mathrm{~g}$ of $\mathrm{Ca}$ ) was administered to all cows at calving and $12 \mathrm{~h}$ after calving as a bolus dose in water, and $100 \mathrm{~g} / \mathrm{d}$ of $\mathrm{CaHPO}_{4} \cdot 2 \mathrm{H}_{2} \mathrm{O}$ (containing $23 \mathrm{~g}$ of $\mathrm{Ca}$ ) was administered to all of the cows for $6 \mathrm{~d}$ postpartum as top-dressing on TMR.

\section{Data and Sample Collection}

The amount of feed offered and refused was recorded daily from $14 \mathrm{~d}$ before calving until $6 \mathrm{~d}$ postpartum. Feed samples were collected once monthly. Samples of the refused feed were collected daily, and their compo-

Table 1. Ingredients of the pellets and TMR fed to dry and lactating cows

\begin{tabular}{|c|c|c|c|c|}
\hline \multirow{2}{*}{$\begin{array}{l}\text { Ingredient, \% of } \\
\text { fresh matter }\end{array}$} & \multicolumn{2}{|c|}{ Pellets } & \multicolumn{2}{|c|}{ TMR } \\
\hline & Control & $\mathrm{DFA}^{1}$ & Dry $^{2}$ & Lact $^{3}$ \\
\hline Corn silage & - & - & 50.0 & 40.5 \\
\hline Grass silage & - & - & 39.0 & 35.7 \\
\hline Concentrate mix & - & - & $8.4^{4}$ & $9.6^{5}$ \\
\hline Grass hay & - & - & - & 2.9 \\
\hline Ear corn silage & - & - & - & 3.6 \\
\hline Beet pulp & - & - & - & 2.3 \\
\hline Rice bran & 24.0 & 20.0 & - & 1.9 \\
\hline Soybean meal & - & - & 2.4 & 1.8 \\
\hline Rolled barley & - & - & - & 1.4 \\
\hline Ground corn & 38.0 & 30.0 & - & - \\
\hline Wheat bran & 38.0 & 30.0 & - & - \\
\hline Vitamin mineral $\operatorname{mix}^{6}$ & - & - & 0.07 & 0.04 \\
\hline Vitamin $\mathrm{E}$ & - & - & 0.07 & - \\
\hline $\mathrm{MgO}$ & - & - & 0.07 & 0.03 \\
\hline $\mathrm{CaCO}_{3}$ & - & - & - & 0.10 \\
\hline DFA III ${ }^{6}$ & - & 20.0 & - & - \\
\hline
\end{tabular}

${ }^{1}$ Difructose anhydride III.

${ }^{2}$ Prepartum period (average from -14 to $-1 \mathrm{~d}$ relative to calving).

${ }^{3}$ Postpartum period (average from 1 to $6 \mathrm{~d}$ relative to calving).

${ }^{4}$ Dry Base 17 (nutrient composition on a DM basis: $20.5 \%$ CP, $27.9 \%$ NDF, $0.28 \%$ Ca, $0.70 \%$ P, $0.35 \% \mathrm{Mg}$, $1.25 \%$ K, $0.04 \%$ Na, 0.15\% S, and 0.38\% Cl; Hokuren Kumiai Shiryo K. K., Hokkaido, Japan).

${ }^{5}$ Mo-Dairy 18 (nutrient composition on a DM basis: $21.4 \% \mathrm{CP}, 24.5 \% \mathrm{NDF}, 1.58 \% \mathrm{Ca}, 0.60 \% \mathrm{P}, 0.31 \% \mathrm{Mg}$, $1.28 \%$ K, $0.23 \%$ Na, 0.38\% S, and 0.41\% Cl; Nippon Formula Feed Manufacturing Co. Ltd., Kanagawa, Japan). ${ }^{6}$ Contents per gram: $5,000 \mathrm{IU}$ of vitamin A, 1,000 IU of vitamin D, $2 \mathrm{mg}$ of vitamin E, $0.2 \mathrm{mg}$ of vitamin $\mathrm{K}_{3}$, $0.5 \mathrm{mg}$ of vitamin $\mathrm{B}_{1}, 1 \mathrm{mg}$ of vitamin $\mathrm{B}_{2}, 0.1 \mathrm{mg}$ of vitamin $\mathrm{B}_{6}, 1 \mathrm{ng}$ of vitamin $\mathrm{B}_{12}, 6 \mathrm{mg}$ of nicotonic acid, $2 \mathrm{mg}$ of choline chloride, $10 \mathrm{mg}$ of pantothenic acid, $156 \mu \mathrm{g}$ of $\mathrm{Mn}\left(\mathrm{MnSO}_{4}\right), 0.7 \mathrm{mg}$ of $\mathrm{Zn}\left(\mathrm{ZnCO}_{3}\right), 50 \mu \mathrm{g}$ of $\mathrm{Fe}\left(\mathrm{FeSO}_{4}\right), 139 \mu \mathrm{g}$ of $\mathrm{Cu}\left(\mathrm{CuSO}_{4}\right), 325 \mu \mathrm{g}$ of $\mathrm{I} \mathrm{Ca}\left(\mathrm{IO}_{3}\right)_{2}, 38 \mu \mathrm{g}$ of $\mathrm{Co}\left(\mathrm{CoSO}_{4}\right), 1 \mathrm{mg}$ of methionine, and 0.5 $\mathrm{mg}$ of lysine hydrochloride. 
Table 2. Chemical composition (\% of DM, unless otherwise noted) of pellets, TMR, and hay that were fed to dry and lactating cows

\begin{tabular}{|c|c|c|c|c|c|c|}
\hline Item & \multicolumn{2}{|c|}{ Pellet } & \multicolumn{2}{|c|}{ Dry $^{1}$} & \multicolumn{2}{|c|}{ Lactating $^{2}$} \\
\hline $\mathrm{CP}$ & 14.4 & 11.5 & 15.0 & 14.9 & 15.4 & 14.8 \\
\hline NDF & 27.5 & 19.3 & 41.6 & 60.3 & 41.3 & 62.4 \\
\hline $\mathrm{ADF}$ & 8.6 & 6.8 & 24.6 & 36.9 & 24.3 & 37.3 \\
\hline Neutral detergent insoluble CP & 1.7 & 1.4 & 2.5 & 4.0 & 2.8 & 5.5 \\
\hline Ether extract & 5.7 & 4.7 & 4.0 & 3.1 & 3.8 & 2.9 \\
\hline Ash & 4.4 & 3.7 & 7.8 & 12.0 & 8.1 & 11.5 \\
\hline $\mathrm{NE}_{\mathrm{L}},{ }^{4} \mathrm{Mcal} / \mathrm{kg}$ of $\mathrm{DM}$ & 1.81 & 1.84 & 1.52 & 1.16 & 1.51 & 1.19 \\
\hline $\mathrm{Ca}$ & 0.07 & 0.07 & 0.40 & 0.42 & 0.65 & 0.45 \\
\hline $\mathrm{P}$ & 0.92 & 0.76 & 0.42 & 0.40 & 0.44 & 0.41 \\
\hline $\mathrm{Mg}$ & 0.40 & 0.35 & 0.24 & 0.24 & 0.27 & 0.24 \\
\hline $\mathrm{K}$ & 1.02 & 0.78 & 2.36 & 3.40 & 2.21 & 3.28 \\
\hline
\end{tabular}

${ }^{1}$ Prepartum period (average from -14 to $-1 \mathrm{~d}$ relative to calving).

${ }^{2}$ Postpartum period (average from 1 to $6 \mathrm{~d}$ relative to calving).

${ }^{3}$ Supplemented with difructose anhydride III.

${ }^{4}$ Calculated according to NRC (2001).

${ }^{5}$ Calculated as $\left(\mathrm{Na}^{+}+\mathrm{K}^{+}\right)-\left(\mathrm{Cl}^{-}+\mathrm{S}^{2-}\right)$ (Ender et al., 1971).

sition was determined weekly (Table 2). The samples were dried in a forced-air oven at $60^{\circ} \mathrm{C}$ for $24 \mathrm{~h}$ and then ground using a Wiley mill (1-mm screen, SM2000; Retsch, Haan, Germany). Subsequently, the contents of $\mathrm{DM}, \mathrm{CP}, \mathrm{NDF}, \mathrm{ADF}$, neutral detergent-insoluble CP, acid detergent-insoluble $\mathrm{CP}$, ADL, ether extract, ash, $\mathrm{Ca}, \mathrm{P}, \mathrm{Mg}, \mathrm{K}, \mathrm{Na}, \mathrm{S}$, and $\mathrm{Cl}$ were determined (Table 2). The $\mathrm{N}$ content was quantified using the Kjeldahl method, and the value was multiplied by 6.25 to calculate the CP content (AOAC International, 2003; method 984.13). The NDF content was determined according to the procedure of Van Soest et al. (1991) using Q-amylase and sodium sulfate. The ADF content was measured according to AOAC International (2003; method 973.18). The neutral detergent-insoluble and acid detergent-insoluble $\mathrm{CP}$ contents were determined according to the procedure of Coblentz et al. (2010). The ADL content was quantified according to AOAC International (2003; method 973.18) and ether extract content according to AOAC International (2003; method 920.39). The ash content was determined after placing the samples in a muffle furnace for $2 \mathrm{~h}$ at $600^{\circ} \mathrm{C}$ (AOAC International, 2003; method 942.05). The concentrations of $\mathrm{Ca}, \mathrm{P}$, $\mathrm{Mg}, \mathrm{K}$, and Na were obtained according to AOAC International (2003; method 985.01). Briefly, the samples were ashed in a muffle furnace for $2 \mathrm{~h}$ at $600^{\circ} \mathrm{C}$, and the ash was dissolved in hydrochloric acid, followed by analysis using inductively coupled plasma spectroscopy (ICPE-9000; Shimadzu Corporation, Kyoto, Japan).
The contents of $\mathrm{S}$ and $\mathrm{Cl}$ were determined using an energy-dispersive fluorescent X-ray spectrometer (JSX3100RII; Jeol Ltd., Tokyo, Japan). The DCAD content $(\mathrm{mEq} / 100 \mathrm{~g}$ of $\mathrm{DM})$ was calculated as $\left(\mathrm{Na}^{+}+\mathrm{K}^{+}\right)-$ $\left(\mathrm{Cl}^{-}+\mathrm{S}^{2-}\right)$ (Ender et al., 1971). The $\mathrm{NE}_{\mathrm{L}}$ content was calculated in accordance with NRC (2001), discounting energy yield on the assumption that a dairy cow ingests 3 times the amount required for normal maintenance. The feed mineral intake was calculated by multiplying the amount of DM intake (difference between the amount of DM offered and the amount of DM refused) and the content of each mineral.

Blood samples were collected from the caudal vein using blood collection tubes (Venoject II VP-P100K; Terumo Corporation, Tokyo, Japan) before feeding at $-21,-14,-7,-3$, and $-1 \mathrm{~d}$ and $0 \mathrm{~h}$ (immediately upon calving), $6,12,24,48,72 \mathrm{~h}$, and 4,5 , and $7 \mathrm{~d}$ relative to calving. The blood samples were centrifuged $(2,000 \times$ $g, 10 \mathrm{~min}$ ) and the resultant serum was stored at $-30^{\circ} \mathrm{C}$ until analysis. The serum $\mathrm{Ca}, \mathrm{P}$, and $\mathrm{Mg}$ concentrations were determined using an automatic biochemical analyzer (TBA120FR; Toshiba Medical Systems Co., Tochigi, Japan). The concentrations of serum parathyroid hormone (PTH) at $-21,-7$, and $-1 \mathrm{~d}, 0,12,24$, and $72 \mathrm{~h}$, and $7 \mathrm{~d}$ relative to calving were determined using a commercial kit (Access Intact PTH; Beckman Coulter Inc., Brea, CA). The serum concentrations of $1,25-(\mathrm{OH})_{2} \mathrm{D}$ at $-1 \mathrm{~d}$ and at $0,12,24$, and $72 \mathrm{~h}$ relative to calving were determined using a commercial RIA kit 
(Immunodiagnostic Systems Ltd., Boldon, UK). The serum concentrations of the cross-linked N-telopeptide of type I collagen (NTX), a bone-resorption marker, were determined at $-21,-7$, and $-1 \mathrm{~d}$, at $0,6,12,24$, 48 , and $72 \mathrm{~h}$, and at 4,5 , and $7 \mathrm{~d}$ relative to calving using a commercial ELISA kit (Osteomark NTX Serum; Alere Medical Co. Ltd., Tokyo, Japan). The serum pH at $-21,-14$, and $-7 \mathrm{~d}$ was determined using a blood gas and electrolyte analyzer (Cobas B 221; Roche Diagnostics Japan, Tokyo, Japan).

The cows were milked twice daily, and the milk yield from each milking was measured and sampled during $6 \mathrm{~d}$ after calving. The Ca concentration of the milk was determined using inductively coupled plasma spectroscopy (ICPE-9000), after $1 \mathrm{~mL}$ of the milk sample was mixed with $0.5 \mathrm{~g}$ of cellulose (Wako Pure Chemical Industries Ltd., Osaka, Japan), incinerated in a muffle furnace for $2 \mathrm{~h}$ at $600^{\circ} \mathrm{C}$ and digested using hydrochloric acid (AOAC International, 2003; method 985.01).

\section{Statistical Analysis}

The data on serum $\mathrm{Ca}, \mathrm{P}, \mathrm{Mg}, \mathrm{PTH}, 1,25-(\mathrm{OH})_{2} \mathrm{D}$, and NTX concentrations and serum $\mathrm{pH}$, feed mineral intake, milk yield, and $\mathrm{Ca}$ concentration of the milk were analyzed using repeated-measures ANOVA (JMP 8.0.2; SAS Institute Inc., Cary, NC); only the feed mineral intake data were separated according to preand postpartum periods. When an interaction between groups and time was detected, these data were analyzed using Student's $t$-test for each sampling period. The transition in the concentration of serum NTX in all of the cows $(\mathrm{n}=74)$ was analyzed using paired $t$-tests. The time required for serum Ca concentrations to recover to a normal range $(9 \mathrm{mg} / \mathrm{dL}$; NRC, 2001) during the postpartum period was calculated by fitting the serum Ca transition cubic function curve for each group and parity.

\section{RESULTS}

The average number of days that DFA III was administered to the DFA group during the prepartum period was $16.6 \pm 1.5 \mathrm{~d}$, with a maximum of $26 \mathrm{~d}$ and a minimum of $7 \mathrm{~d}$. Three cows in the DFA group and 1 cow in the control group carried twins. At calving, 1 cow from the control group required assistance due to dystocia.

\section{Blood Components}

The serum concentrations of $\mathrm{Ca}$ during the prepartum period did not differ according to the treatment and declined in both groups at $0 \mathrm{~h}$ relative to calving. However, the serum Ca was higher in the DFA group than in the control group at $6 \mathrm{~h}(P<0.05), 12 \mathrm{~h}(P<$ $0.01), 24 \mathrm{~h}(P<0.01)$, and $48 \mathrm{~h}(P<0.01)$ relative to calving (Figure 1a). During the postpartum period, the time required for the serum Ca to recover to $9 \mathrm{mg} / \mathrm{dL}$ was shorter in the DFA group than in the control group at each parity (Table 3 ).

The serum concentrations of $\mathrm{P}$ during the prepartum period did not differ according to the treatment and declined in both groups at $0 \mathrm{~h}$ relative to calving. However, the serum $\mathrm{P}$ was significantly higher in the DFA group than in the control group at $6 \mathrm{~h}(P<0.05)$, $12 \mathrm{~h}(P<0.01), 24 \mathrm{~h}(P<0.01)$, and $48 \mathrm{~h}(P<0.01)$ relative to calving (Figure 1b).

The serum concentrations of $\mathrm{Mg}$ during the prepartum period did not differ according to treatment and increased in both groups at $0 \mathrm{~h}$ relative to calving. However, the concentrations of serum $\mathrm{Mg}$ were significantly higher in the DFA group than in the control group at $72 \mathrm{~h}(P<0.05)$ and $4 \mathrm{~d}(P<0.05)$ relative to calving (Figure 1c).

Serum PTH concentrations did not differ between groups during the prepartum period. During the postpartum period, serum PTH concentrations increased at $0 \mathrm{~h}$ relative to calving in both groups and were significantly lower in the DFA group than in the control group at $12 \mathrm{~h}(P<0.05)$ and $24 \mathrm{~h}(P<0.01)$ relative to calving (Figure 2a).

No significant difference was observed in serum $1,25-(\mathrm{OH})_{2} \mathrm{D}$ concentrations between the groups during the prepartum period $(\mathrm{d}-1)$. During the postpartum period, serum $1,25-(\mathrm{OH})_{2} \mathrm{D}$ concentrations increased at 0 and $12 \mathrm{~h}$ relative to calving in both groups and were significantly lower in the DFA group than in the control group at $72 \mathrm{~h}$ relative to calving $(P<0.01$, Figure 2b).

Serum NTX concentrations did not differ significantly in the 2 groups during the peripartum period (Figure 3a). Serum NTX concentrations in all cows were significantly lower at $0,6,12,24,48$, and $72 \mathrm{~h}$ relative to calving than at $-21,4$, and 5 d relative to calving $(P<0.05$, Figure $3 \mathrm{~b})$.

Serum $\mathrm{pH}$ did not differ according to treatment during the prepartum period (Table 4).

\section{Feed Mineral Intake}

We detected no significant difference in the prepartum $\mathrm{Ca}$ and $\mathrm{K}$ intakes of the 2 groups (Table 4 ). However, compared between the groups, postpartum Ca intake was significantly higher $(P<0.05$, Table 4$)$. 
(a)

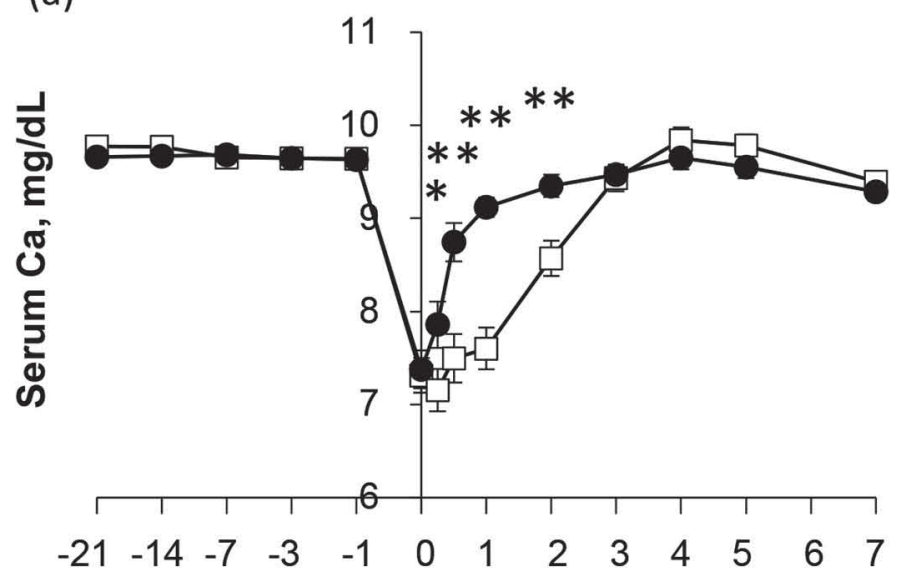

(b)

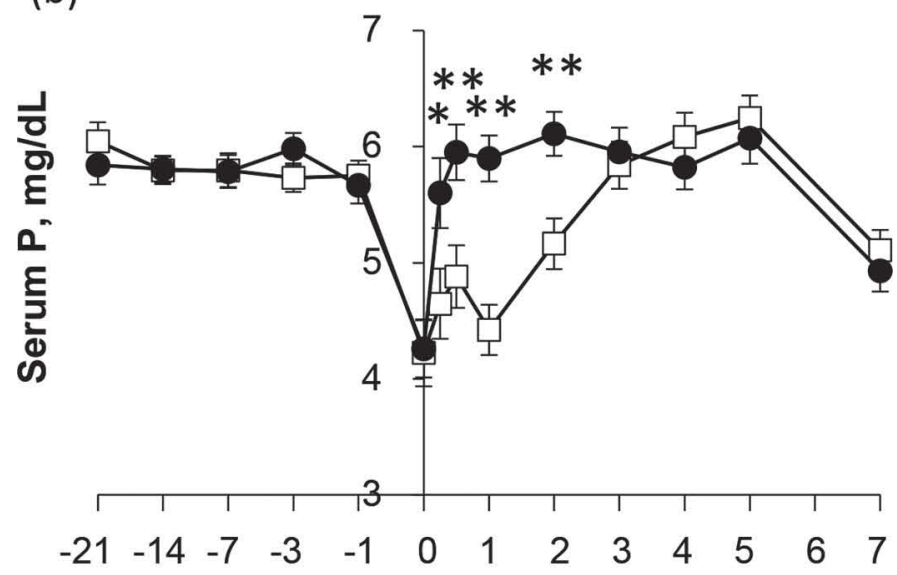

(c)

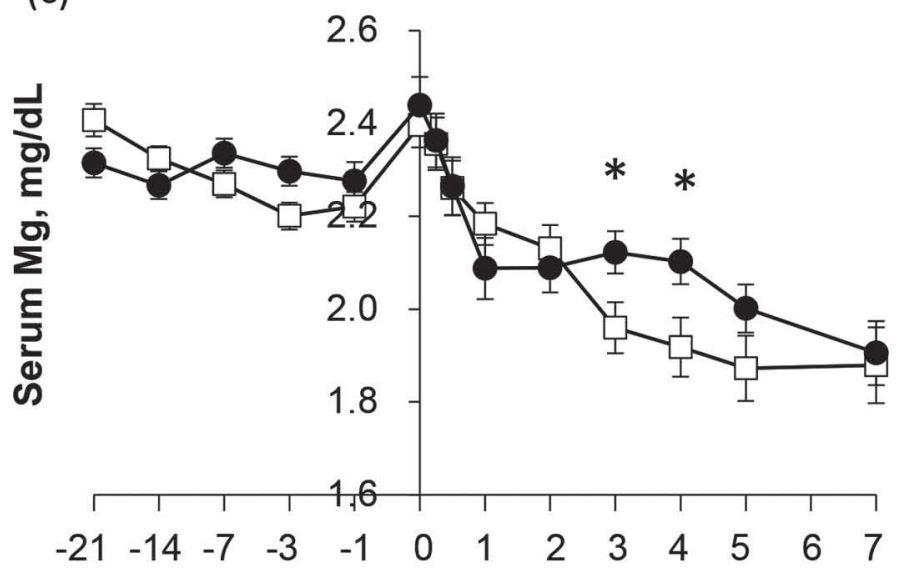

Days relative to calving

Figure 1. Serum calcium (a), phosphate (b), and magnesium (c) during the peripartum period ( -21 to 7 d relative to calving; means \pm SEM) in the control group $(\square ; \mathrm{n}=37)$ and the group supplemented with difructose anhydride III (DFA, $\mathbf{0} \mathrm{n}=37) . *$ and $* *$ indicate significant differences between the groups at each time point $\left({ }^{* *} P<\right.$ $\left.0.01 ;{ }^{*} P<0.05\right)$.
Table 3. The time required for the recovery of the serum calcium content to $9 \mathrm{mg} / \mathrm{dL}$ during the postpartum period ${ }^{1}$

\begin{tabular}{lcccc}
\hline \multicolumn{5}{c}{$\begin{array}{c}\text { Serum Ca recovery time } \\
(=9 \mathrm{mg} / \mathrm{dL})\end{array}$} \\
\cline { 2 - 5 } Parity & \multicolumn{4}{c}{ Control } \\
\hline$\geq 6$ & $74 \mathrm{~h}$ & $(\mathrm{n}=6)$ & $50 \mathrm{~h}$ & $(\mathrm{n}=5)$ \\
5 & $59 \mathrm{~h}$ & $(\mathrm{n}=7)$ & $23 \mathrm{~h}$ & $(\mathrm{n}=8)$ \\
4 & $40 \mathrm{~h}$ & $(\mathrm{n}=4)$ & $26 \mathrm{~h}$ & $(\mathrm{n}=4)$ \\
3 & $60 \mathrm{~h}$ & $(\mathrm{n}=9)$ & $19 \mathrm{~h}$ & $(\mathrm{n}=8)$ \\
2 & $63 \mathrm{~h}$ & $(\mathrm{n}=11)$ & $28 \mathrm{~h}$ & $(\mathrm{n}=12)$ \\
\hline
\end{tabular}

${ }^{1}$ The postpartum serum Ca values for each parity level were fitted to a cubic function curve to calculate the time for the serum Ca concentration to recover to $9 \mathrm{mg} / \mathrm{dL}$.

${ }^{2}$ Supplemented with difructose anhydride III.

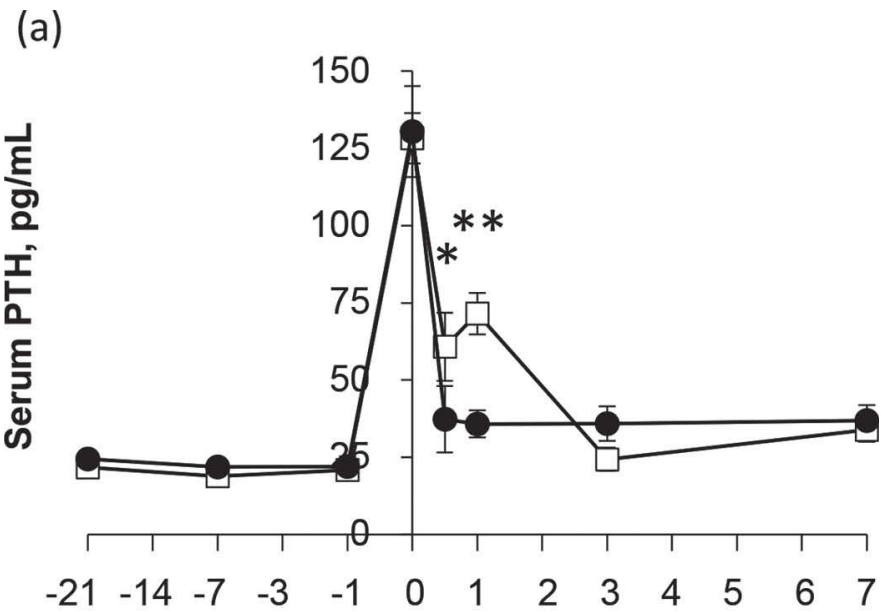

(b)

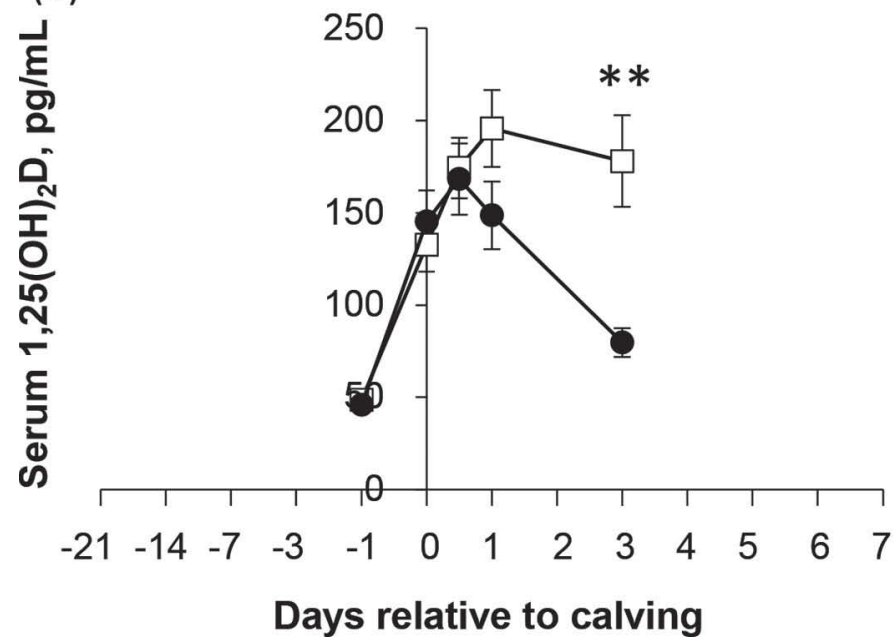

Figure 2. Serum parathyroid hormone (PTH; a) and 1,25-dihydroxyvitamin $\mathrm{D}(\mathrm{b})$ during the peripartum period $(-21$ to $7 \mathrm{~d}$ or $-1 \mathrm{~d}$ to $72 \mathrm{~h}$ relative to calving; means \pm SEM) in the control group ( $\square ; \mathrm{n}=$ 37 ) and the group supplemented with difructose anhydride III (DFA, $\mathbf{0} ; \mathrm{n}=37) .{ }^{*}$ and $* *$ indicate significant differences between the groups at each time point $\left(* * P<0.01 ;{ }^{*} P<0.05\right)$. 


\section{Ca Outflow in Milk}

We found no significant difference in Ca concentrations in the milk of the 2 groups (Table 4). Milk yield was significantly higher in the DFA group than in the control group $(P<0.01$, Table 4$)$. Therefore, the amount of $\mathrm{Ca}$ outflow into the milk was significantly higher in the DFA group $(P<0.01$, Table 4$)$.

\section{DISCUSSION}

The previously mentioned risk factors for hypocalcemia include age, breed, contents of dietary $\mathrm{Ca}$ and $\mathrm{K}$, DCAD status, and hypomagnesemia (van de Braak

(a)

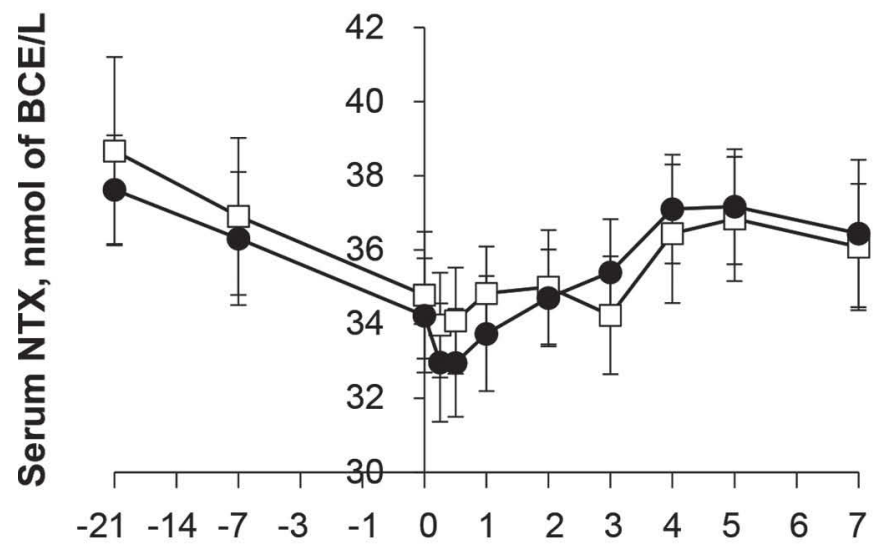

(b)

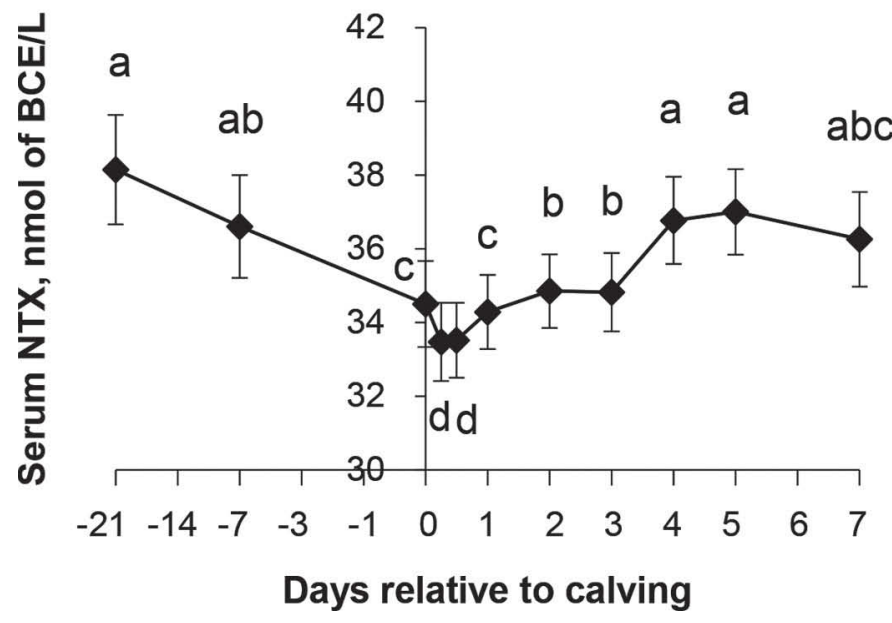

Figure 3. Serum cross-linked N-telopeptide of type I collagen (NTX; means \pm SEM) during the peripartum period $(-21$ to $7 \mathrm{~d}$ relative to calving) in the control group $(\square ; \mathrm{n}=37)$ and the group supplemented with difructose anhydride III (DFA, $\mathbf{0} n=37$ ) (a) and all cows $(\checkmark ; \mathrm{n}=74)(\mathrm{b})$. BCE $=$ bone collagen equivalents. Letters a $\mathrm{b}, \mathrm{c}$, and $\mathrm{d}$ indicate differences at $P<0.05$ at each time point among all cows. et al., 1987; Oetzel, 1991; Goff and Horst, 1997; NRC, 2001). Furthermore, metabolic alkalosis is the most important determinant of the risk of milk fever (Ender et al., 1971). In the present study, parity, breed, offered feed, $\mathrm{Ca}$ and $\mathrm{K}$ intakes, serum $\mathrm{pH}$ during the prepartum period, and serum Mg during the early postpartum period were similar between groups. Therefore, the only difference between the 2 groups was dietary supplementation with DFA III. When the concentration of serum $\mathrm{Ca}$ declines, it is compensated for by bone resorption, intestinal $\mathrm{Ca}$ absorption, and reabsorption by the renal tubules (NRC, 2001). Among these Ca supply routes, reabsorption via renal tubules was found to be crucially important when anionic salt was added (Schonewille et al., 1999). However, in the present study, anionic salt was not added to the feed, and the cows were therefore offered a high-DCAD feed $(+36.2 \mathrm{mEq} / 100 \mathrm{~g})$. Although we could not determine the amount of Ca that was resorbed by the renal tubules, the total amount of Ca that can be recovered by reducing the extent of urinary $\mathrm{Ca}$ excretion is relatively small in parturient cows (Goff, 2006), and no difference in this value was found in the 2 groups. Hence, there were 2 main $\mathrm{Ca}$ supply routes during the early postpartum period: bone resorption and intestinal $\mathrm{Ca}$ absorption.

Bone resorption is inactive during the early postpartum period (Liesegang et al., 2000, 2007; Moreira et al., 2009; Taylor et al., 2009). In the present study, the transition in the concentration of serum NTX, which was used as a bone-resorption marker, suggested that bone resorption was restrained from 0 to $72 \mathrm{~h}$ relative to calving. Nevertheless, we observed a higher serum Ca concentration in the DFA group than in the control group from 6 to $48 \mathrm{~h}$ relative to calving. These results indicated that DFA III promoted Ca absorption by the intestine immediately after calving.

Serum PTH increased at $0 \mathrm{~h}$ relative to calving in both of the groups. When serum $\mathrm{Ca}$ decreases, the parathyroid glands release $\mathrm{PTH}$, which stimulates bone resorption and increases $1,25-(\mathrm{OH})_{2} \mathrm{D}$ synthesis to enhance the rate of active intestinal Ca transport via the transcellular pathway and Ca reabsorption through the renal tubules (NRC, 2001). Metabolic alkalosis induces conformational changes in the PTH receptor, which disturbs the tight binding of PTH to its receptor and impairs the physiological activity of PTH, preventing upregulation of bone resorption and the production of 1,25-(OH) $)_{2} \mathrm{D}$ (Goff et al., 1991, 2014; Phillippo et al., 1994). In the present study, the average serum $\mathrm{pH}$ in both groups was higher than the standard value for alkalemia ( $>7.45$; Constable et al., 1991) because the cows of both groups were offered a high-DCAD feed. Serum Ca concentration was significantly lower in the control group than in the DFA group during 
Table 4. Feed mineral intake, milk yield, and Ca outflow into the milk in the control and DFA (supplemented with difructose anhydride III) groups during the pre- and postpartum periods

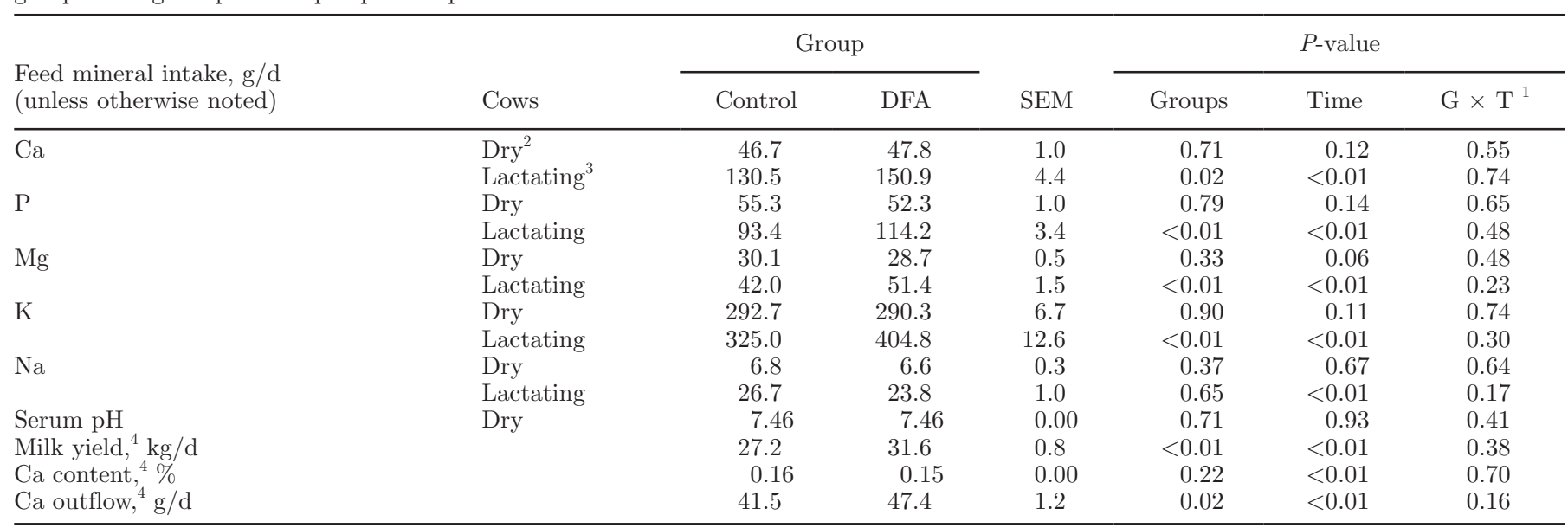

${ }^{1}$ Interaction between the groups and time.

${ }^{2}$ Prepartum period (average from -14 to $-1 \mathrm{~d}$ relative to calving).

${ }^{3}$ Postpartum period (average from 1 to $6 \mathrm{~d}$ relative to calving).

${ }^{4}$ Mean values at $-21,-14$, and $-7 \mathrm{~d}$ relative to calving.

the postpartum period, even though the control group exhibited a high concentration of serum PTH. The reasons for this finding could be the malfunctioning of either the PTH receptor within the bone and kidney or the VDR within the intestinal epithelial cells, or both. Bone resorption was restrained in the early postpartum period, which might have been affected by metabolic alkalosis (Bushinsky, 1996). However, cows in which $1,25-(\mathrm{OH})_{2} \mathrm{D}$ production is delayed or insufficient account for fewer than $10 \%$ of milk fever-affected cows (Goff et al., 1989). Furthermore, many studies have reported that serum $1,25-(\mathrm{OH})_{2} \mathrm{D}$ increases to a level equal to or greater than that of normal cows in the early postpartum period, although these cows were fed high-DCAD feed (Goff and Horst, 1997; Penner et al., 2008), which affected hypocalcemia (Horst et al., 1978; Goff et al., 2014). Similarly, in the present study, serum $1,25-(\mathrm{OH})_{2} \mathrm{D}$ increased in both groups at 0 and $12 \mathrm{~h}$ relative to calving. Therefore, these results suggested that the most significant factor delaying serum Ca recovery in the control group was the lack of reaction to increasing serum $1,25-(\mathrm{OH})_{2} \mathrm{D}$ in the intestine, rather than PTH in the kidney in the early postpartum period because of the decrease in the number of VDR within the intestinal epithelial cells that occurs with aging (Horst et al., 1990). In contrast, even though the DFA group also experienced metabolic alkalosis and a decreasing number of VDR within the intestinal epithelial cells, serum Ca was significantly higher and serum PTH was significantly lower than in the control group during the early postpartum period. Thus, the improvement of serum Ca status of the DFA group occurred due to
DFA III promoting intestinal Ca absorption, which is independent of PTH and 1,25- $(\mathrm{OH})_{2} \mathrm{D}$ during the early postpartum period. Furthermore, the time required to recover a normal range of serum $\mathrm{Ca}(\geq 9 \mathrm{mg} / \mathrm{dL})$ following parturition was shorter in the DFA group than in the control group, even in high-parity cows. Moreover, DFA III promoted Ca absorption via the paracellular pathway of tight junctions in the intestine, a process that is unaffected by aging.

Calcium intake increases significantly during the early postpartum period, providing an increasing amount of Ca that could be absorbed in the intestine (Goff and Horst, 1997). Therefore, these conditions could contribute to the rapid recovery of serum $\mathrm{Ca}$ during the early postpartum period in the DFA group, as intestinal Ca absorption via the paracellular pathway depends on the concentration gradient (Bronner, 1987).

Hypocalcemia generally occurs when the amount of Ca lost to lactation exceeds that of the supplied $\mathrm{Ca}$ (Goff, 2008). In the present study, Ca outflow into the milk was significantly higher in the DFA group than in the control group, even though the time for the recovery of serum Ca during the early postpartum period was shorter in the DFA group. These results suggest that the Ca supply in the DFA group during the early postpartum period exceeded the amount of Ca outflow due to lactation, resulting from the DFA III-induced enhancement of $\mathrm{Ca}$ absorption by the intestine.

In the current study, we observed that serum Ca recovered rapidly during the postpartum period in the DFA group; however, we cannot confirm that DFA treatment affected the decline in the serum $\mathrm{Ca}$ that 
occurred immediately upon calving. In contrast, Sato et al. (2007) observed that the decline in the serum Ca immediately upon calving was prevented by supplementing the diet with DFA III during the close-up period. The difference between the results of the 2 studies may involve the management of the prepartum period. Therefore, further investigation of the conditions under which DFA III shows effects is necessary.

Treatment with DFA III promotes Ca absorption via the paracellular pathway, which occurs through passive diffusion driven by the concentration gradient and is independent of the content of VDR within intestinal epithelial cells. Therefore, DFA III dietary supplementation holds promise by potentially showing a universal effect that could protect older cows from hypocalcemia, as these cows are vulnerable to this condition because of a decreased number of VDR in the intestine.

\section{CONCLUSIONS}

Supplementation with DFA III during the peripartum period appears to promote passive Ca transport in the intestine via the paracellular pathway during the early postpartum period. This effect holds promise for decreasing the incidence of hypocalcemia in older cows, which are vulnerable to hypocalcemia because they have fewer vitamin $\mathrm{D}$ receptors in their intestine.

\section{ACKNOWLEDGMENTS}

The authors are grateful for the assistance provided by Aung Htun (Obhiro University of Agriculture and Veterinary Medicine, Obihiro, Japan), Yasuhiro Suzuki (Obhiro University of Agriculture and Veterinary Medicine, Obihiro, Japan), and the staff of the Field Center of Animal Science and Agriculture of Obihiro University of Agriculture and Veterinary Medicine (Obihiro, Japan).

\section{REFERENCES}

AOAC International. 2003. Official Methods of Analysis. 17th ed. AOAC International, Arlington, VA.

Block, E. 1984. Manipulating dietary anions and cations for prepartum dairy cows to reduce incidence of milk fever. J. Dairy Sci. 67:2939-2948.

Bronner, F. 1987. Calcium absorption, Pages 1419-1435 in Physiology of the Gastrointestinal Tract. 2nd ed. L. R. Johnson, ed. Raven, New York, NY.

Bronner, F. 1998. Calcium absorption-A paradigm for mineral absorption. J. Nutr. 128:917-920.

Bushinsky, D. A. 1996. Metabolic alkalosis decreases bone calcium efflux by suppressing osteoclasts and stimulating osteoblasts. Am. J. Physiol. 271:F216-F222.

Charbonneau, E., D. Pellerin, and G. R. Oetzel. 2006. Impact of lowering dietary cation-anion difference in nonlactating dairy cows: A meta-analysis. J. Dairy Sci. 89:537-548.
Coblentz, W. K., P. C. Hoffman, and N. P. Martin. 2010. Effects of spontaneous heating on forage protein fractions and in situ disappearance kinetics of crude protein for alfalfa-orchardgrass hays packaged in large round bales. J. Dairy Sci. 93:1148-1169.

Constable, P. D., G. St Jean, B. L. Hull, D. M. Rings, and G. F. Hoffsis. 1991. Prognostic value of surgical and postoperative findings in cattle with abomasal volvulus. J. Am. Vet. Med. Assoc. 199:892-898.

Curtis, C. R., H. N. Erb, C. J. Sniffen, R. D. Smith, P. A. Powers, M C. Smith, M. E. White, R. B. Hillman, and E. J. Pearson. 1983. Association of parturient hypocalcemia with eight periparturient disorders in Holstein cows. J. Am. Vet. Med. Assoc. 183:559-561.

DeGaris, P. J., and I. J. Lean. 2008. Milk fever in dairy cows: A review of pathophysiology and control principles. Vet. J. 176:58-69.

Edmonson, A. J., I. J. Lean, L. D. Weaver, T. Farver, and G. Webster. 1989. A body condition scoring chart for Holstein dairy cows. J. Dairy Sci. 72:68-78.

Ender, F., I. W. Dishington, and A. Helgebostad. 1971. Calcium balance studies in dairy cows under experimental induction and prevention of hypocalcaemic paresis puerperalis. Z. Tierphysiol. Tierernahr. Futtermittelkd. 28:233-256.

Goff, J. P. 2006. Macromineral physiology and application to the feeding of the dairy cow for prevention of milk fever and other periparturient mineral disorders. Anim. Feed Sci. Technol. 126:237-257.

Goff, J. P. 2008. The monitoring, prevention, and treatment of milk fever and subclinical hypocalcemia in dairy cows. Vet. J. 176:50-57.

Goff, J. P., and R. L. Horst. 1990. Effect of subcutaneously released $24 \mathrm{~F}-1,25$-dihydroxyvitamin D3 on incidence of parturient paresis in dairy cows. J. Dairy Sci. 73:406-412.

Goff, J. P., and R. L. Horst. 1993. Oral administration of calcium salts for treatment of hypocalcemia in cattle. J. Dairy Sci. 76:101-108.

Goff, J. P., and R. L. Horst. 1997. Effects of the addition of potassium or sodium, but not calcium, to prepartum ratios on milk fever in dairy cows. J. Dairy Sci. 80:176-186.

Goff, J. P., R. L. Horst, F. J. Mueller, J. K. Miller, G. A. Kiess, and H. H. Dowlen. 1991. Addition of chloride to a prepartal diet high in cations increases 1,25 -dihydroxyvitamin $\mathrm{D}$ response to hypocalcemia preventing milk fever. J. Dairy Sci. 74:3863-3871.

Goff, J. P., A. Liesegang, and R. L. Horst. 2014. Diet-induced pseudohypoparathyroidism: A hypocalcemia and milk fever risk factor. J. Dairy Sci. 97:1520-1528.

Goff, J. P., T. A. Reinhardt, and R. L. Horst. 1989. Recurring hypocalcemia of bovine parturient paresis is associated with failure to produce 1,25-dihydroxyvitamin D. Endocrinology 125:49-53.

Goings, R. L., N. L. Jacobson, D. C. Beitz, E. T. Littledike, and K. D. Wiggers. 1974. Prevention of parturient paresis by a prepartum, calcium-deficient diet. J. Dairy Sci. 57:1184-1188.

Hibbs, J. W., and W. D. Pounden. 1955. Studies on milk fever in dairy cows. IV. Prevention by short-time, prepartum feeding of massive doses of vitamin D. J. Dairy Sci. 38:65-72.

Hirase, T., S. Kawashima, E. Y. Wong, T. Ueyama, Y. Rikitake, S. Tsukita, M. Yokoyama, and J. M. Staddon. 2001. Regulation of tight junction permeability and occludin phosphorylation by Rhoa-p160ROCK-dependent and -independent mechanisms. J. Biol. Chem. 276:10423-10431.

Horst, R. L., J. P. Goff, and T. A. Reinhardt. 1990. Advancing age results in reduction of intestinal and bone 1,25-dihydroxyvitamin D receptor. Endocrinology 126:1053-1057.

Horst, R. L., J. P. Goff, T. A. Reinhardt, and D. R. Buxton. 1997. Strategies for preventing milk fever in dairy cattle. J. Dairy Sci 80:1269-1280.

Horst, R. L., N. A. Jorgensen, and H. F. DeLuca. 1978. Plasma 1,25-dihydroxyvitamin $\mathrm{D}$ and parathyroid hormone levels in paretic dairy cows. Am. J. Physiol. 235:E634-E637.

Karczewski, J., and J. Groot. 2000. Molecular physiology and pathophysiology of tight junctions. III. Tight junction regulation by intracellular messengers: Differences in response within and between epithelia. Am. J. Physiol. Gastrointest. Liver Physiol. 279:G660G665.

Kikuchi, H., T. Nagura, M. Inoue, T. Kishida, H. Sakurai, A. Yokota, K. Asano, F. Tomita, K. Sayama, and Y. Senba. 2004. Physical, 
chemical and physiological properties of difructose anhydride III produced from inulin by enzymatic reaction. J. Appl. Glycosci. 51:291-296.

Kurosaki, N., O. Yamato, F. Mori, S. Imoto, and Y. Maede. 2007. Preventive effect of mildly altering dietary cation-anion difference on milk fever in dairy cows. J. Vet. Med. Sci. 69:185-192.

Liesegang, A., C. Chiappi, J. Risteli, J. Kessler, and H. D. Hess. 2007. Influence of different calcium contents in diets supplemented with anionic salts on bone metabolism in periparturient dairy cows. J. Anim. Physiol. Anim. Nutr. (Berl.) 91:120-129.

Liesegang, A., R. Eicher, M. L. Sassi, J. Risteli, M. Kraenzlin, J. L. Riond, and M. Wanner. 2000. Biochemical markers of bone formation and resorption around parturition and during lactation in dairy cows with high and low standard milk yields. J. Dairy Sci. 83:1773-1781.

Lindmark, T., Y. Kimura, and P. Artursson. 1998. Absorption enhancement through intracellular regulation of tight junction permeability by medium chain fatty acids in Caco-2 cells. J. Pharmacol. Exp. Ther. 284:362-369.

Matsumoto, D., M. Takagi, H. Hasunuma, Y. Fushimi, M. Ohtani, T. Sato, K. Okamoto, F. Shahada, T. Tanaka, and E. Deguchi. 2009. Effects of oral administration of difructose anhydride III on selected health and blood parameters of group-housed Japanese black calves during the preweaning period. Asian-australas. J. Anim. Sci. 22:1640-1647.

Mineo, H., H. Hara, N. Shigematsu, Y. Okuhara, and F. Tomita. 2002. Melibiose, difructose anhydride III and difructose anhydride IV enhance net calcium absorption in rat small and large intestinal epithelium by increasing the passage of tight junctions in vitro. J. Nutr. 132:3394-3399.

Moreira, V. R., L. K. Zeringue, C. C. Williams, C. Leonardi, and M. E. McCormick. 2009. Influence of calcium and phosphorus feeding on markers of bone metabolism in transition cows. J. Dairy Sci. 92:5189-5198.

Nakai, T., S. Murata, H. Kikuchi, T. Sato, H. Sadoya, M. Ohtani, M. Hanada, and M. Okamoto. 2007. Detection of dietary difructose anhydride III in the duodenal digesta of steers. Nihon Chikusan Gakkaiho 78:57-61. (in Japanese with English abstract).

NRC. 2001. Nutrient Requirements of Dairy Cattle. 7th rev. ed. Natl. Acad. Sci., Washington, DC.

Nusrat, A., J. R. Turner, and J. L. Madara. 2000. Molecular physiology and pathophysiology of tight junctions IV. Regulation of tight junctions by extracellular stimuli: Nutrients, cytokines, and immune cells. Am. J. Physiol. Gastrointest. Liver Physiol. 279:G851G857.

Oetzel, G. R. 1991. Meta-analysis of nutritional risk factors for milk fever in dairy cattle. J. Dairy Sci. 74:3900-3912.

Penner, G. B., G. F. Tremblay, T. Dow, and M. Oba. 2008. Timothy hay with a low dietary cation-anion difference improves calcium homeostasis in periparturient Holstein cows. J. Dairy Sci. 91:1959-1968.

Phillippo, M. G., W. Reid, and I. M. Nevison. 1994. Parturient hypocalcaemia in dairy cows: Effects of dietary acidity on plasma minerals and calciotrophic hormones. Res. Vet. Sci. 56:303-309.

Ramberg, C. F. Jr., E. K. Jhomson, R. D. Fargo, and D. S. Kronfeld. 1984. Calcium homeostasis in cows, with special reference to parturient hypocalcemia. Am. J. Physiol. 246:R698-R704.

Reinhardt, T. A., J. D. Lippolis, B. J. McCluskey, J. P. Goff, and R. L. Horst. 2011. Prevalence of subclinical hypocalcemia in dairy herds. Vet. J. 188:122-124.

Saito, K., and F. Tomita. 2000. Difructose anhydrides: Their mass-production and physiological function. Biosci. Biotechnol. Biochem. 64:1321-1327.
Saitou, M., M. Furuse, H. Sasaki, J. D. Schulzke, M. Fromm, H. Takano, T. Noda, and S. Tsukita. 2000. Complex phenotype of mice lacking occludin, a component of tight junction strands. Mol. Biol. Cell 11:4131-4142.

Sakurai, H., A. Yokota, Y. Sumita, Y. Mori, H. Matsui, and F. Tomita. 1997. Metabolism of DFA III by Arthrobacter sp. H65-7: Purification and properties of a DFA III hydrolysis enzyme (DFA IIIase). Biosci. Biotechnol. Biochem. 61:989-993.

Sato, T., M. Hanada, M. Ohtani, T. Nakai, M. Teramura, H. Sadoya, T. Takahashi, and A. Hongo. 2012. Effect of difructose anhydride III on serum immunoglobulin G concentration in newborn calves. J. Dairy Sci. 95:5336-5339.

Sato, T., H. Kikuchi, T. Nakai, H. Sadoya, M. Hanada, and M. Okamoto. 2006. Effect of ruminal bacteria on degradability of difructose anhydride III. Nihon Chikusan Gakkaiho 77:395-399. (in Japanese with English abstract)

Sato, T., T. Nakai, H. Sadoya, M. Ohtani, M. Hanada, and M. Okamoto. 2007. Effect of difructose anhydride III on hypocalcemia in dairy cows after calving. Nihon Chikusan Gakkaiho 78:37-43. (in Japanese with English abstract)

Schonewille, T. J., A. T. Van't Klooster, H. Wouterse, and A. C. Beynen. 1999. Hypocalcemia induced by intravenous administration of disodium ethylenediaminotetraacetate and its effects on excretion of calcium in urine of cows fed a high chloride diet. J. Dairy Sci. 82:1317-1324.

Suzuki, T., and H. Hara. 2004. Various nondigestible saccharides open a paracellular calcium transport pathway with the induction of intracellular calcium signaling in human intestinal Caco-2 cells. J. Nutr. 134:1935-1941.

Suzuki, T., and H. Hara. 2006. Difructose anhydride III and sodium caprate activate paracellular transport via different intracellular events in Caco-2 cells. Life Sci. 79:401-410.

Suzuki, T., H. Hara, T. Kasai, and F. Tomita. 1998. Effects of difructose anhydride III on calcium absorption in small and large intestines of rats. Biosci. Biotechnol. Biochem. 62:837-841.

Takagi, M., H. Hasunuma, D. Matsumoto, T. Obi, K. Takase, M. Ohtani, T. Sato, U. Watanabe, K. Okamoto, T. Tanaka, C. Tshering, and E. Deguchi. 2011. Effect of daily oral administration of difructose anhydride III on health status, blood parameters and faecal shedding of coliform bacteria of Japanese black calves during the pre-weaning period. Anim. Nutr. Feed Technol. 11:147-158.

Tang, V. W., and D. A. Goodenough. 2003. Paracellular ion channel at the tight junction. Biophys. J. 84:1660-1673.

Taylor, M. S., K. F. Knowlton, M. L. McGilliard, W. S. Swecker, J. D. Ferguson, Z. Wu, and M. D. Hanigan. 2009. Dietary calcium has little effect on mineral balance and bone mineral metabolism through twenty weeks of lactation in Holstein cows. J. Dairy Sci. 92:223-237.

Teramura, M., T. Nakai, M. Itoh, T. Sato, M. Ohtani, C. Kawashima, and M. Hanada. 2015. Difructose anhydride (DFA) III promotes calcium absorption from the duodenum in cattle. J. Dairy Sci 98:2533-2538.

van de Braak, A. E., A. T. van't Klooster, and A. Malestein. 1987. Influence of a deficient supply of magnesium during the dry period on the rate of calcium mobilisation by dairy cows at parturition. Res. Vet. Sci. 42:101-108.

Van Soest, P. J., J. B. Robertson, and B. A. Lewis. 1991. Methods for dietary fiber, neutral detergent fiber and non-starch polysaccharide in relation to animal nutrition. J. Dairy Sci. 74:3583-3597. 